\title{
Factors impacting logging costs: A case study in the Northeast, US
}

\author{
By René Germain ${ }^{1 *}$, Jamie Regula ${ }^{1}$, Steven Bick² and Lianjun Zhang ${ }^{1}$
}

\begin{abstract}
Understanding business costs is critical to the economic viability of logging businesses. Various harvest and logger characteristics impact logging costs. This study sought to examine factors influencing logging costs of ground-based harvesting systems across 23 logging jobs. On-site interviews were conducted with loggers across New York and Northern Pennsylvania. Machine rates and throughput accounting were used to calculate logging costs. Regression analysis identified significant variables influencing per unit logging costs. Two independent variables, harvested volume per area and owner/operator experience, were found to be statistically significant when predicting per unit logging costs. Other variables such as harvest area, hours spent implementing Best Management Practices and total linear distance of access system were positively related to total logging costs.
\end{abstract}

Key words: forest management, logging costs, economic sustainability, best management practices, logger viability

\section{RÉSUMÉ}

Il est essentiel de bien comprendre les coûts des entreprises pour assurer la viabilité économique de l'industrie forestière. Plusieurs aspects propres à la récolte et au bûcheron ont une incidence sur les coûts d'exploitation. Cette étude visait à examiner les facteurs qui influent sur les coûts d'exploitation des systèmes de récolte au sol dans 23 chantiers d'exploitation. On a effectué des interviews avec des bûcherons à la grandeur de l'État de New York et du nord de la Pennsylvanie. Les taux payés pour la machinerie ainsi que la méthode des coûts variables des matières ont été utilisés pour calculer les coûts d'exploitation. L'analyse de régression a permis d'identifier les variables qui ont un impact réel sur les coûts unitaires d'exploitation. Deux de ces variables indépendantes, soit le volume récolté par unité de surface et l'expérience du propriétaire ou de l'opérateur, se sont avérées significatives pour estimer le coût unitaire d'exploitation. D'autres variables comme la surface récoltée, les heures consacrées à la mise en œuvre des bonnes pratiques de gestion et la longueur totale du réseau d'accès montraient aussi une corrélation positive avec les coûts d'exploitation totaux.

Mots-clés : aménagement forestier, coûts d'exploitation, durabilité économique, meilleures pratiques de gestion, viabilité du bûcheron

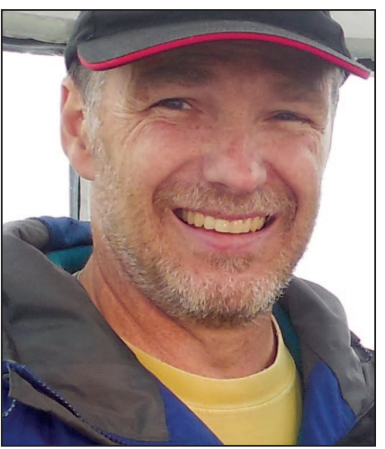

René Germain

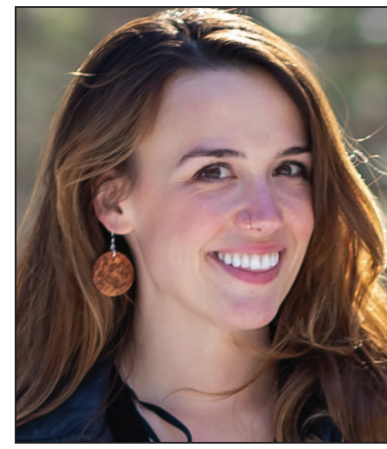

Jamie Regula

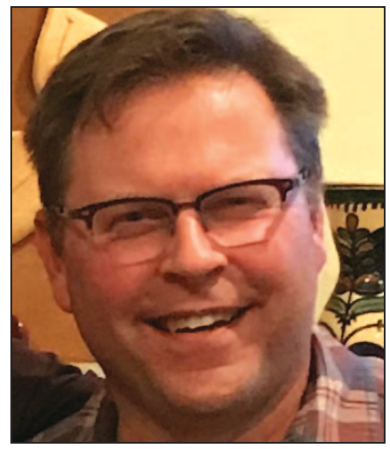

Steven Bick



Lianjun Zhang

\footnotetext{
${ }^{1}$ SUNY College of Environmental Sciences and Forestry, Syracuse, NY, 13210 USA; * corresponding author's e-mail rhgermai@esf.edu

${ }^{2}$ Northeast Forests Inc., Thendara, NY, 13472, USA
} 


\section{Introduction}

The three major ground-based harvesting systems common in the Northeast US include cut-to-length, tree-length, and whole-tree. Each system consists of a combination of equipment, including chainsaws, feller bunchers, harvesters, cable skidders, grapple skidders, forwarders, slashers, loaders, chippers and splitters which can add up to millions of dollars in equipment. Whole tree systems tend to require the most equipment while cut-to-length and tree-length can function with fewer pieces, such as chainsaws or harvesters for felling, and skidders or forwarders for moving (Leon and Benjamin 2012). External variables affecting logging costs for harvest systems include timber sale characteristics such as harvest area, harvest volume (e.g., average volume per stem), the access system (e.g., skidding distance, landings, access roads), topography (e.g., slope), and extent of Best Management Practices (BMPs). The degree to which these factors influence logging costs will vary based on both logger and job characteristics.

Past studies have examined some of these factors that influence logging costs. For instance, decreasing harvest area on private forestlands can contribute to declining economies of scale associated with higher fixed costs (Cubbage et al. 1989). The relationship between harvest intensity (harvested volume per unit area) and logging costs is well documented in the literature. Per unit costs are higher and profits decrease when harvest intensity is low (Kluender et al. 1998; Wagner et al. 2000; Han-Sup et al. 2004; Arriagada et al. 2008). The access system, including forest roads, skid trails, and landings, can have a profound impact on logging costs. However, there are few studies based in the Northeast US that isolate the relationship between access systems and logging costs (Kelly et al. 2017; Regula et al. 2018). Studies based in other regions of the US have documented a direct relationship between skid trails and logging costs (Greulich 2003; Contreras et al. 2016). In general, steeper slopes have been associated with increased road costs, environmental impacts and significantly higher logging costs (Erickson et al. 1991; Arriagada et al. 2008), but few studies have examined this relationship in the Northeast. Closely related to the access system and topography is the implementation of BMPs. Loggers most often incur BMP costs directly or pass them on to landowners or sawmills by reducing stumpage prices or increasing contract rates (Kelly et al. 2017). Several studies have attempted to estimate BMP costs (Lickwar et al. 1992; Shaffer et al. 1998; Kelly et al. 2016), but few in the Northeast have related the impact of BMP implementation on per unit logging costs.

This study sought to examine those factors influencing per unit logging costs for loggers utilizing tree-length harvest systems across New York State and Northern Pennsylvania. With a tree-length system, the stem is skidded to the landing with either a cable or grapple skidder and then processed into logs, pulpwood or firewood with either a chainsaw or slasher. Specifically, we examined the following independent variables for their effect on per unit logging costs: harvest area, number of days on the job, harvested cubic volume cut per area, additional time spent on BMPs, total linear distance of skid trails, average distance of skid trails, average slope and contractor experience in years. Understanding the impact of these variables on logging costs is critical to the future viabil- ity of loggers in this region, and beyond. A recent study by Regula et al. (2018) suggests that logger viability appears under threat as less than half of loggers examined were profitable on individual timber sales.

\section{Methods}

The study was conducted on logging jobs located primarily in New York, supplemented by two jobs located just across the state line in northeastern Pennsylvania. Specifically, in New York, three logging jobs were conducted in the Adirondack region, three were located in the Catskill region, while the bulk were located in the southern and central tier of New York. Working in partnership with procurement and consulting foresters, thirty-one loggers were identified for scheduled harvesting operations in the summer and fall of 2016. The contractors were contacted by phone and asked to participate in the study. Of these, 23 agreed to participate and provided sufficient information to complete the analysis. The 23 study participants had the following personnel breakdown: eight single person operators, eight 2-person crews, four 4-person crews, and three 3-person crews. There was no compensation for participants.

Interviews were conducted at the harvest site at the close out of each job to ensure the logger fully reported clean-up costs and number of working days. Questions focused primarily on type of equipment, operating and ownership costs, and special characteristics of the harvest. Following the interview, a global positioning system (GPS) was used to map the landing(s) and skid trails. We documented both the total linear distance of all skid trails on the site as well as the average skid distance, given that most practitioners think in terms of average skid distance on a particular job. The average was calculated by taking half the distance of any given skid trail from the landing, summing the distances and averaging. If there was more than one landing, we divided the midpoints by the number of landings. The associated forester provided important information on each timber sale, including harvest area, maps, number of sawtimber stems marked for harvest (by species), actual sawtimber volume cut, pulpwood/firewood volume cut and other useful descriptive information. This allowed us to verify volumes provided by the logger.

The products generated at each harvest included various quantities of sawtimber (bdft), pulpwood (tons), and firewood (cords). To estimate total volume from each job, all products were converted to cubic feet. This unit was chosen because it allows for reasonably accurate conversions from original product units as well as conversion to cubic meters $\left(\mathrm{m}^{3}\right)\left(35.32 \mathrm{ft}^{3}=1 \mathrm{~m}^{3}\right)$. The conversion factors were one cord is equal to $85 \mathrm{ft}^{3}$ of pulpwood and $128 \mathrm{ft}^{3}$ of stacked firewood, one ton (hardwood) is equal to $37.78 \mathrm{ft}^{3}$, and $1 \mathrm{MBF}$ equals $83.34 \mathrm{ft}^{3}$. Scribner log rule was used by the participating sawmills to estimate sawtimber volumes, making conversions uniform. Since the Scribner log rule is an output-based measurement system, using the lumber conversion rate of $83.34 \mathrm{ft}^{3}$ is appropriate, given the final volumes were logbased volumes (Verrill et al. 2004).

\section{Harvest cost analysis}

PATH 2.1, a spreadsheet software program that calculates and applies costs of the entire production system was used to calculate harvesting costs and financial results for individual 
jobs. Path 2.1 incorporates machine rates, business overhead and job specific costs to determine job costs and then applies thoughput accounting to determine financial results (Bick 2017). Throughput accounting is a simplified means of quantifying financial results (Goldratt 2004) and is adapted specifically for logging in PATH 2.1.

During the interview, specific equipment information was acquired for each machine the logger used in his business. This allowed us to calculate individual machine rates by determining fixed, operating, and labor costs - expressed in terms of dollars per productive machine hour $(\$ / P M H)$ and other harvesting costs in PATH 2.1. PMH is defined as the time a machine is performing its scheduled function (Brinker et al. 2002). Factors affecting variable costs include fuel use and price, oil use and price, maintenance and repair, depreciation, and other miscellaneous logging costs. Depreciation is the amount of value the equipment loses while in use. It is important to note that PATH 2.1 treats depreciation as a variable cost in PMH calculations and uses accumulated actual depreciation over the course of individual harvesting jobs as the primary measurement of investment for each job (Table 1) (Germain et al. 2016; Bick 2017).

Table 1. Selected Variables Included in PATH 2.1 Calculations and Associated Assumptions

\begin{tabular}{l} 
Input \\
\hline Machine Hours un \\
Significant Overha \\
or Repairs \\
Percent of Cost to \\
Depreciation
\end{tabular}
Expected Annual
Use (hours)

Residual Value

\section{Repairs and Maintenance Cost per PMH}

Hourly Operator Costs

\section{Ratio of Machine Hours to Operator Time}

\section{Annual Insurance Costs}

Daily Overhead

\section{Description}

The machine hours until a significant overhaul or repairs.

The percent of the machine's value that will be depreciated between the original acquisition cost and the next significant repair.

The number of hours the machine is used in a year on average.

This is the salvage value.

Hourly repairs and maintenance costs.

This includes the operators' hourly wage, workmen's compensation and benefits.

This is the percent of the operator's time that is actually spent operating the machine.

The cost of replacement insurance on the machine.

This is used to capture other business expenses (e.g. non-productive labor, liability insurance, advertising, pick-up truck expenses, legal and professional services, office expenses, and other items typically found in IRS Form 1040 Schedule C).

\section{Assumptions \& Supplemental Sources}

This information allows calculation of a periodic hourly rate, rather than a lifetime rate. Actual depreciation of machines is steeper at the beginning of their useful life; this information accounts for that. Significant overhauls require recalculation of a new rate as they constitute further investment in the machine.

This input allows calculation of a machine rate for a segment of the machine's life, more closely matching the actual loss of machine value that occurs. PATH 2.1 uses hourly depreciation as the measure of investment in individual harvesting jobs.

This input is used in converting the fixed cost of insurance and the alternative annual return for cash invested in the equipment into hourly rates.

This value represents a fixed (non-depreciating) amount of investment in the machine. An annual return on this investment is expected. PATH 2.1 accounts for the return on this investment that is included in individual jobs.

Values were sourced from dealership websites and the Northern Logger publication.

If sufficient information was not provided by the logger, ranges were supplied by Germain et al. (2016).

To calculate hourly operator cost to the employer we doubled the operator's hourly wage to include benefits. If the owner operator does not know, an hourly wage of $\$ 40$ was used.

This is used to calculate the cost of the labor per productive machine hour. For example, if the hourly operator cost is $\$ 30$ and the ratio of machine hours to operator's time is $80 \%$; the cost per machine hour is $\$ 37.50(\$ 30 \div 0.8)$.

This only applied if the machine was actually insured (usually as a requirement of the financing).

When loggers did not know, industry averages provided by Steven Bick (2016) were used for the following harvest operation sizes:

- Small: 1-2-person cable skidding operation: \$200-250/day

- Medium: maintenance shop and a mix of older and new equipment: \$275-325/day

- Larger: maintenance shop and office staff, 3 skidders and newer feller-buncher, loader \& slasher combination: $\$ 820 /$ day

Industry averages were taken from direct consultations with individual loggers from outside this study.

Any portion of the owner's time that is not captured as a machine operator is included here. 
Table 2. Harvest site characteristics by area and details of the access system

\begin{tabular}{|c|c|c|c|c|}
\hline ID & $\begin{array}{c}\text { Area } \\
\text { (ha) }\end{array}$ & $\begin{array}{c}\text { Total } \\
\text { Linear } \\
\text { Distance } \\
\text { of Access } \\
\text { System } \\
\text { (meters) }\end{array}$ & $\begin{array}{c}\text { Average } \\
\text { Slope (\%) }\end{array}$ & $\begin{array}{c}\text { Average } \\
\text { Skid } \\
\text { Distance } \\
\text { (meters) }\end{array}$ \\
\hline A & 13.35 & 2065.32 & 16 & 316.08 \\
\hline B & 4.45 & 700.43 & 8 & 350.52 \\
\hline C & 48.56 & 2554.83 & 12 & 638.56 \\
\hline D & 6.07 & 576.07 & 7 & 288.04 \\
\hline E & 40.47 & 1224.99 & 25 & 612.65 \\
\hline F & 14.16 & 1739.19 & 14 & 869.59 \\
\hline G & 57.87 & 3983.43 & 4 & 663.85 \\
\hline $\mathbf{H}$ & 19.42 & 2581.66 & 6 & 1290.83 \\
\hline I & 24.28 & 2996.79 & 11 & 749.20 \\
\hline $\mathbf{J}$ & 14.57 & 559.61 & 7 & 279.81 \\
\hline $\mathbf{L}^{*}$ & 16.19 & 1644.40 & 12 & 822.35 \\
\hline M & 12.14 & 1511.50 & 10 & 755.60 \\
\hline $\mathbf{N}$ & 34.40 & 1128.37 & 9 & 563.88 \\
\hline O & 36.42 & 2810.26 & 12 & 1405.13 \\
\hline $\mathbf{P}$ & 23.47 & 1644.70 & 23 & 822.35 \\
\hline $\mathbf{Q}$ & 14.16 & 1937.61 & 13 & 968.65 \\
\hline $\mathbf{R}$ & 121.41 & 8838.59 & 10 & 2209.50 \\
\hline S & 80.94 & 2841.65 & 12 & 1420.67 \\
\hline $\mathbf{T}$ & 32.37 & 2405.18 & 18 & 1202.74 \\
\hline $\mathbf{U}$ & 80.94 & 2475.28 & 7 & 1237.49 \\
\hline V & 2.02 & 1179.88 & 33 & 589.79 \\
\hline $\mathbf{W}$ & 23.07 & 2006.50 & 6 & 1003.40 \\
\hline $\mathbf{X}$ & 31.16 & 2697.78 & 7 & 644.04 \\
\hline
\end{tabular}

${ }^{*}$ Logger $\mathrm{K}$ was initially included in the analysis but was later identified and removed from the data set for not providing sufficient information

\section{Harvest site analysis}

ArcGIS 10.4.1 software by Environmental Systems Research Institute was used to analyze total linear distance of the skid trails and slope data collected on the GPS unit. Digital Elevation Model (DEM) files were obtained from the National Elevation Dataset (NED) clearinghouse. A 1/3 arc-second (10 meters $(\mathrm{m})$ ) resolution was available for the entirety of New York and Pennsylvania. Using the ArcGIS 10.4.1 software, the DEM raster data was converted over to percent slope using the Slope tool. Average slope and total distance were then calculated for each individual skid trail using the Calculate Geometry tool.

\section{Regression analysis}

All statistical analyses were carried out using SAS $9.4^{\circ}$ statistical software (SAS Institute, Inc. 2009). Prior to statistical tests and modeling, dependent and independent variables were assessed for normal distribution. Once all variables were determined to have linear relationships, multiple linear regression analyses were conducted to (1) fit ordinary least squares (OLS) regression models with all independent variables as the benchmark, and (2) find "best" models using the stepwise regression method. An analysis was performed to assess the significance of the independent variables on per unit logging costs $(\mathrm{Y})$. The independent variables include:
Table 3. Descriptive statistics for all dependent and independent variables

\begin{tabular}{lccccc}
\hline Variable & N & Mean & $\begin{array}{c}\text { Std } \\
\text { Dev }\end{array}$ & $\begin{array}{c}\text { Mini- Maxi- } \\
\text { mum mum }\end{array}$ \\
\hline $\begin{array}{l}\text { Per Unit Logging } \\
\quad \text { Costs (US\$) }\end{array}$ & 23 & 54.08 & 19.92 & 24.67 & 93.68 \\
Area (ha) & 23 & 32.69 & 28.96 & 2.02 & 121.41 \\
Days on Job & 23 & 29.87 & 20.98 & 3.00 & 75.00 \\
Cubic Meters per Hectare & 23 & 27.52 & 18.09 & 4.97 & 64.37 \\
BMP Hours & 23 & 8.22 & 7.79 & 0 & 40.00 \\
Total Skid Distance (m) & 23 & 2265 & 1670 & 560 & 8838 \\
Average Skid Distance (m) & 23 & 857 & 453 & 280 & 2209 \\
Average Percent Slope & & & & & \\
$\quad$ of Skid Trails & 23 & 12.26 & 6.93 & 4.0 & 33.0 \\
Years of Ownership & 23 & 18.96 & 11.23 & 3.00 & 40.00 \\
\hline
\end{tabular}

- $\mathrm{X}_{1}=$ Area: harvest area (hectares (ha))

- $\mathrm{X}_{2}=$ Days: number of days on the job

- $\mathrm{X}_{3}=$ Cubic: cubic volume per area harvested $\left(\mathrm{m}^{3} / \mathrm{ha}\right)$

- $\mathrm{X}_{4}=$ BMP: hours spent on Best Management Practices

- $\mathrm{X}_{5}=$ Total Access System Distance: skid trail length (m)

- $\mathrm{X}_{6}=$ Average Skid Distance $(\mathrm{m})$

- $\mathrm{X}_{7}=$ Slope: average percent slope of skid trails

- $\mathrm{X}_{8}=$ Years: number of years the owner/operator has owned business (owner experience)

The following OLS model was used to determine the full model for predicting logging costs:

$Y=\beta_{0}+\beta_{1} X_{1}+\beta_{2} X_{2}+\beta_{3} X_{3}+\beta_{4} X_{4}+\beta_{5} X_{5}+\beta_{6} X_{6}+\beta_{7}$ $\mathrm{X}_{7}+\beta_{8} \mathrm{X}_{8}+\epsilon$

where $Y$, and $X_{1}-X_{8}$ are defined as above, $\beta_{0}-\beta_{8}$ are regression coefficients to be estimated from the data, and $\epsilon$ is the model random error. The final model with each independent variable statistically significant at $\alpha=0.05$ level was considered to be the best model for the small sample size and variable nature of the data collected. To determine the "best" model, stepwise selection regression was applied to the data set. Variables included in the model are determined by two significance levels. The significance level to enter (SLE) is used to set which variables are included in the model. The significance level to stay (SLS) is used to determine which variables ultimately stay in the model. Given the small sample size and social nature of the data we used an SLE of 0.15 and an SLS of 0.05 which would account for variability. Stepwise selection regression was applied to all eight predictor variables for the response variable. The full and the "best" models were evaluated by model fitting statistics, including the coefficient of determination $\left(\mathrm{R}^{2}\right)$, adjusted coefficient of determination $\left(\mathrm{R}_{\mathrm{a}}^{2}\right.$ ), mean squared errors (MSE), Akaike Information Criteria (AIC) (Sakamoto et al. 1986), predictive sum of squares (PRESS), standardized regression coefficients, and a residual analysis.

\section{Results}

The majority of the contractors (83\%) had over a decade of experience as owners of a logging business, and $43 \%$ with over two decades of experience. This is based on the year they 
established their business and does not include any previous logging experience for another company. Nearly half of the logging equipment being utilized (48\%) was made between 1990-1999, followed by 2000-2009 (33\%), 1980-1989 (16\%), and 2010-present (3\%).

The average harvest area was 33 ha with a range of 2-121 ha. The mean harvest volume was $28 \mathrm{~m}^{3} /$ ha, ranging from 5 $\mathrm{m}^{3} /$ ha to $64 \mathrm{~m}^{3} / \mathrm{ha}$. The total linear distance of the skid trails across the individual logging jobs averaged 2265 meters, with a range of $560-8839$ meters. The average skid distance from the central landing (s) across the harvest sites was 857 meters, with a range of 280 to 2209 meters (Tables $2 \& 3$ ). The average slope of skid trails was $12 \%$.

The loggers spent an average of 30 days on their respective logging job, with a range of 5 to 75 days. The average cost of operating various logging equipment across the 23 logging jobs was as follows: feller bunchers $(\$ 74.80 / \mathrm{PMH})$, skidders (\$71.04/PMH), dozers (\$68.65/PMH), loaders $(\$ 68.12 /$ $\mathrm{PMH})$, and chainsaws $(\$ 43.14 / \mathrm{PMH})$. These means include hourly wages, (including workmen's compensation, insurance and fringe benefits), for employees and business owners. The age of the logging equipment was influential in the final cost estimates.

A total of $17334 \mathrm{~m}^{3}$ were extracted from all the harvests. Firewood comprised $38 \%$ of the total volume, followed by sawtimber at $34 \%$ and pulpwood at $28 \%$ of the total volume. The average unit cost to cut, skid and land the harvested volume was $\$ 54.08 / \mathrm{m}^{3}$, with a range of $\$ 24.67-93.68 / \mathrm{m}^{3}$ (Table 4 ).

Although the focus of this study was on per unit costs, we did assess the relationship between our eight independent variables and total logging costs. As expected, harvest area ( $\rho$

Table 4. Logging job total and per area volumes harvested in cubic volume with associated total and unit costs

\begin{tabular}{|c|c|c|c|c|c|c|}
\hline ID & $\begin{array}{c}\text { Harvest } \\
\text { Area } \\
\text { (ha) }\end{array}$ & $\begin{array}{c}\text { Total } \\
\text { Volume } \\
\left(\mathrm{m}^{3}\right)\end{array}$ & $\mathrm{m}^{3} / \mathrm{ha}$ & $\begin{array}{l}\text { Total } \\
\text { PMH }\end{array}$ & $\begin{array}{l}\text { Total } \\
\text { Costs }\end{array}$ & $\begin{array}{r}\text { Unit } \\
\text { Cost } \\
\left(\$ / \mathrm{m}^{3}\right)\end{array}$ \\
\hline A & 13.35 & 184 & 13.8 & 196 & $\$ 15,680$ & $\$ 85.18$ \\
\hline B & 4.45 & 216 & 48.6 & 340 & $\$ 11,815$ & $\$ 54.66$ \\
\hline $\mathrm{C}$ & 48.56 & 312 & 6.4 & 242 & $\$ 23,277$ & $\$ 74.61$ \\
\hline $\mathrm{D}$ & 6.07 & 128 & 21.1 & 121 & $\$ 7,711$ & $\$ 60.11$ \\
\hline $\mathrm{E}$ & 40.47 & 201 & 5.0 & 175 & $\$ 13,611$ & $\$ 67.61$ \\
\hline F & 14.16 & 73 & 5.2 & 96 & $\$ 6,876$ & $\$ 93.68$ \\
\hline G & 57.87 & 3,014 & 52.1 & 840 & $\$ 74,359$ & $\$ 24.67$ \\
\hline $\mathrm{H}$ & 19.42 & 1,052 & 54.1 & 561 & $\$ 31,264$ & $\$ 29.73$ \\
\hline I & 24.28 & 645 & 26.6 & 425 & $\$ 29,370$ & $\$ 45.53$ \\
\hline $\mathrm{J}$ & 14.57 & 401 & 27.5 & 316 & $\$ 17,714$ & $\$ 44.20$ \\
\hline $\mathrm{L}$ & 16.19 & 907 & 56.1 & 424 & $\$ 31,957$ & $\$ 35.22$ \\
\hline $\mathrm{M}$ & 12.14 & 399 & 32.9 & 120 & $\$ 10,020$ & $\$ 25.12$ \\
\hline $\mathrm{N}$ & 34.40 & 821 & 23.9 & 399 & $\$ 31,992$ & $\$ 38.96$ \\
\hline $\mathrm{O}$ & 36.42 & 2,345 & 64.4 & 1400 & $\$ 94,088$ & $\$ 40.13$ \\
\hline $\mathrm{P}$ & 23.47 & 728 & 31.0 & 364 & $\$ 28,051$ & $\$ 38.52$ \\
\hline Q & 14.16 & 484 & 34.2 & 320 & $\$ 35,872$ & $\$ 74.07$ \\
\hline $\mathrm{R}$ & 121.41 & 2,041 & 16.8 & 1,855 & $\$ 143,642$ & $\$ 70.39$ \\
\hline S & 80.94 & 726 & 9.0 & 480 & $\$ 39,008$ & $\$ 53.74$ \\
\hline $\mathrm{T}$ & 32.37 & 561 & 17.3 & 414 & $\$ 30,092$ & $\$ 53.63$ \\
\hline $\mathrm{U}$ & 80.94 & 500 & 6.2 & 640 & $\$ 42,554$ & $\$ 85.06$ \\
\hline V & 2.02 & 39 & 19.5 & 27 & $\$ 2,213$ & $\$ 56.14$ \\
\hline W & 23.07 & 1,030 & 44.7 & 420 & $\$ 34,858$ & $\$ 33.84$ \\
\hline $\mathrm{X}$ & 31.16 & 525 & 16.9 & 320 & $\$ 30,962$ & $\$ 58.96$ \\
\hline
\end{tabular}

$=0.761)$, days on the job $(\rho=0.720)$, hours implementing BMPs $(\rho=0.738)$, and total skidding distance $(\rho=0.879)$ were significantly related to total logging costs. Only two independent variables were significantly related to per unit logging costs: cubic volume per area harvested $(\rho=-0.726)$ and owner /operator experience $(\rho=-0.276)$. Consequently, as harvest intensity and owner/operator experience increases, per unit logging costs decrease.

\section{Regression analysis}

OLS with stepwise regression was used to estimate the impact of harvest area $\left(\mathrm{X}_{1}\right)$, days on the job $\left(\mathrm{X}_{2}\right)$, cubic volume per area harvested $\left(\mathrm{m}^{3} / \mathrm{ha}\right)\left(\mathrm{X}_{3}\right)$, hours spent on BMPs $\left(\mathrm{X}_{4}\right)$, skid trail length of access system $(\mathrm{m})\left(\mathrm{X}_{5}\right)$, average skid distance (m) $\left(X_{6}\right)$, average percent slope of skid trails $\left(X_{7}\right)$, and the number of years the owner/operator has owned his business had on per unit logging costs $\left(\mathrm{X}_{8}\right)$. Before the best model for per unit logging costs could be determined, a full model which included all independent variables was tested. This model was statistically significant ( $\mathrm{p}$-value $<0.0043$ ). However, only X3 and X8 were statistically significant at $\alpha=0.05$. No multicollinearity was detected between the eight independent variables in the full model according to Variance Inflation Factor (all VIF <6).

Stepwise regression was subsequently conducted to identify which independent variables would produce a statistically significant best model ( $\mathrm{p}$-value $<0.0001$ ) with a $\mathrm{R}^{2}$ of 0.6476 , and $\mathrm{R}^{2}$ of 0.6124 (Table 5), and included two variables-cubic volume per area harvested $\left(\mathrm{X}_{3}\right)$ and number years of experience $\left(\mathrm{X}_{8}\right)$. The best model is noted as follows:

$$
\hat{Y}=88.8462-0.8362 \mathrm{X}_{3}-0.6203 \mathrm{X}_{8}
$$

To compare the two models ("full" versus "best"), we looked at $\mathrm{R}^{2}, \mathrm{R}^{2}$, MSE, AIC, and PRESS. Table 6 summarizes the model fitting statistics. The best model was statistically a better fit for the data than the full model, having comparable $\mathrm{R}^{2}$ and $\mathrm{R}_{\mathrm{a}}^{2}$ values and lower MSE, AIC, and PRESS values.

\section{Discussion}

While variables influencing logging costs may seem obvious and intuitive, quantifying and predicting the degree to which such site and logger characteristics contribute to our understanding of operating expenses is essential to long-term success in the industry. The model identified the following two statistically significant variables which influence and can predict per unit logging costs: volume per area harvested and owner/operator experience. Increases in both the volume harvested per hectare and operator experience resulted in lower per unit logging costs, with the latter having the least effect on the dependent variable. The independent variables which were not significant in the model were harvest area, number of days on the job, hours spent on BMPs, total linear distance of access system, average skid distance and slope. Although not significant in the unit cost regression model, harvest area, number of days on the job, hours spent on BMPs and total access system distance were all significantly related to total logging costs and influential to overall profitability. In fact, Regula et al. (2018) reported that total harvest site acreage, harvested volume per acre, and hours spent implementing BMPs were all found to be statistically signifi- 
Table 5. Model fitting comparison of full and best models for logging costs

\begin{tabular}{lccccc}
\hline Model & $\mathbf{R}^{2}$ & $\mathbf{R}^{2}{ }_{\mathbf{a}}$ & MSE & AIC & PRESS \\
\hline Full OLS & 0.7420 & 0.5946 & 160.83 & 123.43 & 6529.32 \\
Reduced (Best) & 0.6477 & 0.6124 & 153.77 & 118.60 & 3980.05 \\
\hline
\end{tabular}

cant when predicting the profitability of a specific logging job.

Our results corroborate other findings on the influence of harvest intensity on per unit logging costs. As would be expected, we found that per unit logging costs are inversely related to the volume harvested per unit area. A preponderance of the literature addresses the issue of volume harvested per unit area via stem size. All these studies report increasing per unit costs with smaller stem size and correspondingly lower harvest intensity per area (Kluender et al. 1998; Wagner et al. 2000; Han-Sup 2004; Li et al. 2006). Unfortunately, we did not monitor average stem diameter across our study sample; however, it is important to note that our sample featured hardwood sawtimber-driven harvests featuring relatively high average stem diameters to meet sawmill log specifications.

Although we did not specifically assess operator skill, we did examine owner/operator experience in years as a variable within the model. This "experience" variable proved to be significant in predicting per unit costs. We found that as experience increases per unit costs decrease. Over $80 \%$ of our sample had a decade or more of experience as an owner/operator of a logging business, while nearly half had two decades of experience. The productivity on a job site depends on the abilities and skill level of the operators. As loggers gain experience, they usually gain skill. Since the variability in performance can range greatly among different operators and for a given individual over time, it can be challenging for business owners and researchers to isolate variables and quantify their direct influence (Purfürst and Erler 2011). Characteristics such as fine motor skills, the ability to plan ahead, and the capability to handle multiple working elements simultaneously have been linked to higher productivity levels which can lower per unit costs (Harstela 2004; Peltola 2004; Ranta 2004; Väätäinen et al. 2004). Looking specifically at the relationship between productivity and experience can also be useful when assessing the human influence on productivity. Egan (2009) found that the average age of logging business owners in New York is 46.5 with 12.4 years of formal education and 25 years of logging experience. Since most loggers do not have a formal education in logging, most knowledge of logging operations comes from on-the-job training. A national study completed by Xu et al. (2014) reported logging equipment operators performed adequately after 12 months on the job while chainsaw operators ranged from 6 to 36 months. Other studies have reported operators reaching acceptable levels of performance around 8 to 12 months or in productive machine hours between 1000 and 1500 hours (Purfürst 2010). Although it may take more time to become proficient on various machines, these studies all indicate that level of experience is directly related to production ability. It is important to recall that our sample included eight single person operators who had been in business for over a decade and eight 2-person crews with very little turnover. This level of experience translates into a high skill level, ultimately contributing to the significance of "experience" in the model.

Closely related to experience is the level of formal training and certification. We did ask the business owners whether they were Trained Logger Certified (TLC) under the New York Logger Training program. All 23 loggers in the sample reported participating in the program, but many stated that their TLC was not current. The NY TLC website was referenced to verify which loggers were up-to-date with all courses and current with TLC. In total, $57 \%$ of business owners were current with TLC, but it should be noted that the NY TLC website was considerably out-of-date and under maintenance when referenced.

Previous studies have noted the impact of the access system on economic and environmental conditions of harvesting operations (Contreras et al. 2016; Kizha and Han-Sup 2016). Our results found that the total linear distance of skid trails was linked to higher total logging costs, which is supported by research conducted in other regions of the US (Kochenderfer 1970; Anderson et al. 1976; Greulich 2003). Although it may seem obvious, designing skid trails to reduce skidding distance also lowers skidding costs which is one of the largest cost components of timber harvesting (Greulich 2003). We also examined average skid distance, but it was not significantly related, most likely due to the more narrow range of values when using an average versus a total linear distance. It is important to note that adherence to BMPs may actually increase the length of the access system (Germain and Munsell 2005).

Related to the access system is the role of slope and topography on logging costs. Although not a predictive variable in our model, slope can play a determinant role in logging costs when equipment must operate on steep slopes. In the Northeast, skidding is still the predominant method for extracting timber due to simplicity, species, and small parcel sizes (Erickson et al. 1991; Regula et al. 2018). Rubber-tired skidders are most effective for removing timber from moderately steep sites due to their flexibility, cost advantages, modest skill requirement, and reduced weather sensitivity. However, slopes over $40 \%$ can begin to limit the mobility and efficiency of rubber-tired skidders and can adversely impact site quality (Stuart and Carr 1991). Arriagada et al. (2008) examined the cost of thinning with six harvesting methods in the western US and reported that slope increased ground-based harvest system costs between $\$ 15$ to $\$ 35$ per ha for every one percent increase in slope. Erickson et al. (1991) conducted a time and motion study in West Virginia to develop productivity and cost estimators for the skidding component of ground-based logging systems operating on steep terrain. They found that as line pull distances increased, productive time also increased, which in turn reduced productivity and resulted in increased skidding costs of approximately $\$ 60$ for each additional three meter increment of pull distance per turn. The majority of the logging jobs in our study averaged slopes less than $15 \%$, with only one job with average slopes above $30 \%$. Minimal topographic variability in the sample contributed to its lack of significance in the model. Incidentally, the one job with steep terrain occurred on a small woodlot $(<4 \mathrm{ha})$ with a harvesting intensity of nearly $20 \mathrm{~m}^{3} / \mathrm{ha}$. The harvesting costs were just over $\$ 56 / \mathrm{m}^{3}$, only slightly higher than the study mean of $\$ 54 / \mathrm{m}^{3}$. 
Also related with the access system is the implementation of BMPs. BMPs typically include guidelines on the implementation and maintenance of forest roads, skid trails, log landings, streamside management zones, stream crossings, wetland protection, timber harvesting, and site preparation. When properly implemented, BMPs have been proven to protect and maintain water quality both during and after logging operations (Cristan et al. 2016). We identified the number of hours implementing BMPs as significantly related to total logging costs. Regula et al (2018) reported that hours implementing BMPs was a significant factor in predicting profitability on individual logging jobs. It should be noted that field work for this study was conducted during an official drought. The dry weather minimized the need for some BMPs on individual jobs. During a normal rain year, more BMPs may have needed to be implemented, thereby increasing total costs. Since loggers are often tasked with BMP implementation and incur direct costs, it is important for them to understand their costs on a per area or per unit basis to better negotiate contract rates with sawmills and landowners.

\section{Conclusions}

This study sought to examine those factors that influence logging costs from job to job across a variable forested landscape. The intensity of the harvest $\left(\mathrm{m}^{3} / \mathrm{ha}\right)$ along with logger experience were significant in predicting per unit costs. Our results showed an average unit cost of $\$ 54.03 / \mathrm{m}^{3}$ with a range of $\$ 24.67-93.68 / \mathrm{m}^{3}$. Regula et al $(2018)$ reported a break-even point of approximately $\$ 49.44 / \mathrm{m}^{3}$, suggesting the majority of our sample on these particular logging jobs did not make a profit. This highlights the importance of understanding one's respective logging costs. Harvesting operations in the Northeast US are characterized by challenging site conditions and unpredictable physical environments. Understanding the factors affecting logging costs and productivity is important for long-term viability of businesses and future management decisions. Without an experienced and skilled logging workforce most forest management activities cannot be implemented.

\section{References}

Anderson, H., M. Hoover and K. Reinhart. 1976. Forests and water: Effects of forest management on floods, sediment, and water supply. USDA For. Serv. Gen. Tech. Rep. PSW-Forest and Range Experiment Station, Berkeley, CA. 115 p.

Arriagada, R. A., F.W. Cubbage, K.L. Abt and R.J. Huggett. 2008. Estimating harvest costs for fuel treatments in the West. Forest Prod. J. 58(7): 24-30.

Bick, S. 2017. Planning \& Analysis in Timber Harvesting 2.1. Old Forge, NY: Northeastern Loggers' Association. 43 p.

Brinker, R. W., J. Kinnard, B. Rummer and B. Landford. 2002. Machine rates for selected forest harvesting machines. USDA For. Serv. Gen. Tech. Rep., Alabama Agriculture Experiment Station, Auburn. 32 p.

Contreras, M. A., D.L. Parrott and W. Chung. 2016. Designing skid trail networks to reduce skidding cost and soil disturbance for ground-based timber harvesting operations. Forest Sci. 62(1): 48-58. Cristan, R. W. Aust, C. Bolding, S. Barrett, J. Munsell and E. Schilling. 2016. Effectiveness of forestry best management practices in the United States: Literature review. Forest Ecol. Manage. 360: 133-151.
Cubbage, F. P. Wojtkowski and S. Bullard. 1989. Cross-sectional estimation of empirical southern United States pulpwood harvesting cost functions. Can. J. For. Res. 19: 759-767.

Egan, A. 2009. Characteristics of New York's Logging Businesses and Logging Business Owners. North. J. Appl. For. 26(3): 106-110. Erickson, M. D., C.C. Hassler and C.B. LeDoux. 1991. Productivity and cost estimators for conventional ground-based skidding on steep terrain using preplanned skid roads. Proceedings of the Council on Forest Engineering Annual Meeting. Nanaimo, British Columbia. pp. 92-96.

Germain, R.H. and J. Munsell. 2005. How much land is needed for the harvest access system on NIPF dominated by northern hardwoods? North. J. Appl. For. 22(4): 243-247.

Germain, R.H., S. Bick, M. Kelly, J. Benjamin and W. Farrand. 2016. A case study of three high-performing contract loggers with distinct harvest systems: Are they thriving, striving or just surviving? Forest Prod. J. 66(1): 97-105.

Goldratt, E.M. 2004. The Goal: A process of ongoing improvement, $3^{\text {rd }}$ ed. North River Press Publishing Co. Great Barrington, MA. 384 p. Greulich, F. E. 2003. Transporting Networks in Forest Harvesting: Early Development Theory. Proceedings of the International Seminar on New Roles of Plantation Forestry Requiring Appropriate Tending and Harvesting Operations. Tokyo, Japan. pp. 57-65.

Han-Sup, H.S., H. Lee and L. Johnson. 2004. Economic feasibility of an integrated harvesting system for small-diameter trees in southwest Idaho. Forest Prod. J. 54(2): 21-27.

Harstela, P. 2004. The competence of the forest-machine operator and tactic knowledge. Development Project in Forest Machine Based Training. Joensuu, Finland.

Kelly, M. C., R.H. Germain and S. Bick. 2017. Impacts of forestry best management practices on logging costs and productivity in the Northeastern USA. J. Forest. 115(6): 503-512.

Kizha, A. and H. Han-Sup. 2016. Processing and sorting forest residues: Cost, productivity and managerial impacts. Biomass Bioenergy 93: 97-106.

Kluender, R., D. Lortz, W. McCoy, B. Stokes and J. Klepac. 1998. Removal intensity and tree size effects on harvesting cost and profitability. Forest Prod. J. 48(1): 54-59.

Kochenderfer, J. N. 1970. Erosion Control on Logging Roads in the Appalachians. Res. Pap. NE-158. Upper Darby, PA: US, USDA For. Serv. $28 \mathrm{p}$.

Leon, B. H. and J.G. Benjamin. 2012. A survey of business attributes, harvest capacity and equipment infrastructure of logging businesses in the Northeast forest. The Northern Forest Logging Industry Assessment. 36 p.

Li, Y., J. Wang, G. Miller and J. McNeel. 2006. Production economics of harvesting small diameter hardwood stands in central Appalachia. Forest Prod. J. 56(3): 81-86.

Lickwar, P., C. Hickman and F.W. Cubbage. 1992. Costs of protecting water quality during harvesting on private forestlands in the southeast. South. J. Appl. Forest. 16(1): 13-20.

Peltola, A. 2004. Improving the operator training in the futureSimulator/machine manufacturer perspective. Development Project in Forest Machine-Based Training. Joensuu, Finland.

Purfürst, T. 2010. Learning curves of harvester operations. Croat. J. For. Engin. 31(2): 89-97.

Purfürst, F. T. and J. Erler. 2011. The human influence on producitvity in harvest operators. Int. J. For. Engin. 22(2): 15-22.

Ranta, P. 2004. Possibilities to develop forest machine simulator based education with technology. Development Project in Forest Machine-Based Training. Joensuu, Finland.

Regula, J. R.H Germain, S. Bick and L. Zhang. 2018. Assessing the economic viability of loggers operating tree-length harvest systems in the Northeast. J. Forest. 116(4): 347-356.

SAS Institute Inc. 2009. SAS/STAT Sodtware. Available online at https://www.sas.com/en_us/software/analytics/stat.html. Retrieved January, 2017. 
Sakamoto, I. U. and M.G. Kitagawa. 1986. Akaike Information Criterion Statistics. Dordrecht, Netherlands: D. Reidel Publishing Company 290 p.

Shaffer, R. M., H.L. Haney Jr., E.G. Worrell and W.M. Aust. 1998. Forestry BMP implementation costs for Virginia. Forest Prod. J. 48(9): 27-29.

Stuart, W. B. and J.L. Carr. 1991. Harvesting impacts on steep slopes in Virginia. Proceedings of the $8^{\text {th }}$ Central Hardwood Forest Conference. University Park, PA. pp. 67-81.

Väätäinen, K., L. Sikanen and A. Asikainen. 2004. Feasibility of excavator-based harvesting in thinnings of peatland forests. Int. J. For. Engin. 15(1): 103-111.
Verrill, S., V.L. Herian and H. Spelter. 2004. Estimating the board foot to cubic foot ratio. USDA For. Serv. Research Paper FPL-RP616. $18 \mathrm{p}$.

Wagner, F. G., C.E. Fiedler and C.E. Keegan. 2000. Processing value of small-diameter sawtimber at conventional stud sawmills and modern high-speed, small-log in the western United States-A comparison. West. J. Appl. Forest. 15(4): 208-212.

Xu, Y., M. Smidt and Y. Zhang. 2014. Logging worker wage, performance, and experience. For. Prod. J. 64(5): 210-216. 